\title{
Mannens farlige overgangsalder
}

\begin{abstract}
Man får ikke mange treff på «climacterium virile» i PubMed. Er det fordi fenomenet ikke eksisterer? Temaet var aktuelt på 1800-tallet og ble tatt opp igjen i 1930-årene - og «denne mannlige overgangsalder anerkjennes vel nu av de fleste», hevder forfatteren av denne epistelen fra Tidsskriftet nr. 6/1930. Det finnes til og med to overgangsaldre - det «lille» klimakterium i 40-årene og det «store» i 65-årsalderen, da «mannens liv er mere truet enn ellers». Som eksempel på dette siste trekkes den franske president Félix Faures endelikt frem. Han døde i armene til sin berømte/beryktede elskerinne Marguerite Steinheil, senere lady Abinger, som måtte smugles ut av Élyséepalasset. Forfatteren konkluderer med Horats' ord «Driver du naturen ut med fork, kommer den ustanselig igjen», selvfølgelig sitert på latin (Tidsskr Nor Lægeforen 1930; 50: 326-7).
\end{abstract}

\section{Climakterium virile.}

Spørsmålet: Climacterium virile er - som H.’s lille artikkel i «Tidsskriftet» nr. 2 viser - likeså interessant som gammelt, og der hersker fremdeles stor meningsforskjel herom blant de forfattere som har behandlet temaet.

Tilstedeværelsen av denne mannlige overgangsalder anerkjennes vel nu av de fleste. Men tidspunktet for dens inntreden settes yderst forskjellig, hvilket viser, at saken er både komplisert, ofte basert vesentlig på formodninger og under alle omstendigheter underkastet yderst individuelle variasjoner.

Mens således tidspunktet for klimakteriets inntreden av Va $11 \mathrm{e}$ -

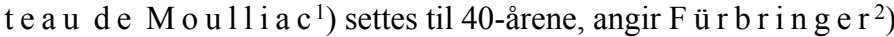
65-års alderen som den kritiske. Denne variasjon i anskuelsene, som vel er meget eldre enn de citerte forfattere, forklarer måskje betegnelsen det «store» klimakterium i 65 -års alderen i motsetning til det «lille» i 40-årene.

Det er heller ingen enighet om hvori de virile klimakteriske forandringer består. En sistering av spermaproduksjonen i likhet med ovulasjonens ophør hos kvinnen er iallfall ikke bevist som nogen konstant foreteelse. Tvert imot er den vel yderst sjelden og da oftest patologisk.

Derimot kan man vel slutte sig til den mening, som forfektes av den kjente neurolog $\mathrm{Kurt} \mathrm{Mende},^{3}$ ) at der hos mannen i 40årene (eller senere) inntrer visse forandringer i de interne kjertler, $\mathrm{i}$ hjerne, arterier o.s.v. (jvfr. sklerosen) med nedsettelse av muskelkraften, syns- og hørselsevnen - og potensen. Det siste kan jo virke særlig ubehagelig, når evnen står i alt for stort misforhold til ydelseskravet, og leder av og til til psykiske depresjonstilstander av ganske alvorlig art. I denne aldersperiode antas det også, at mannens liv er mere truet enn ellers.

Hvordan man nu enn ser på det, så er kjernepunktet for mange den rent seksuelle side av saken. Selv om der på dette punkt ofte ikke inntrer nogen s $t$ ø r r e defekt, så er vel en viss avtagen det almindelige. Og i denne forbindelse har den gamle sats hos Eduard von $\mathrm{H}$ a r t m a n n i hans Philosophie des Unbewuszten sin særskilte gyldighet: at coitus ikke skal utøves for å skaffe sig en lyst-følelse - men for å befri sig for en ulystfølelse. Utøvelse på kommando eller ved hjelp av kunstige irritamenter kan hos gamle menn lett tenkes å stille for store krav også til cirkulasjonsorganene, så at en apopleksi kan bli følgen. Det historiske eksempel herpå er jo som bekjent den franske president F a u re, som døde midt i en omfavnelse. Den elskede spilte i den påfølgende kriminalprocess en stor rolle.

Det faktum, at eldre menn kan vise en sterk potens, motbeviser ikke den almindelige regel. Men som regel kan vel den eldre mann

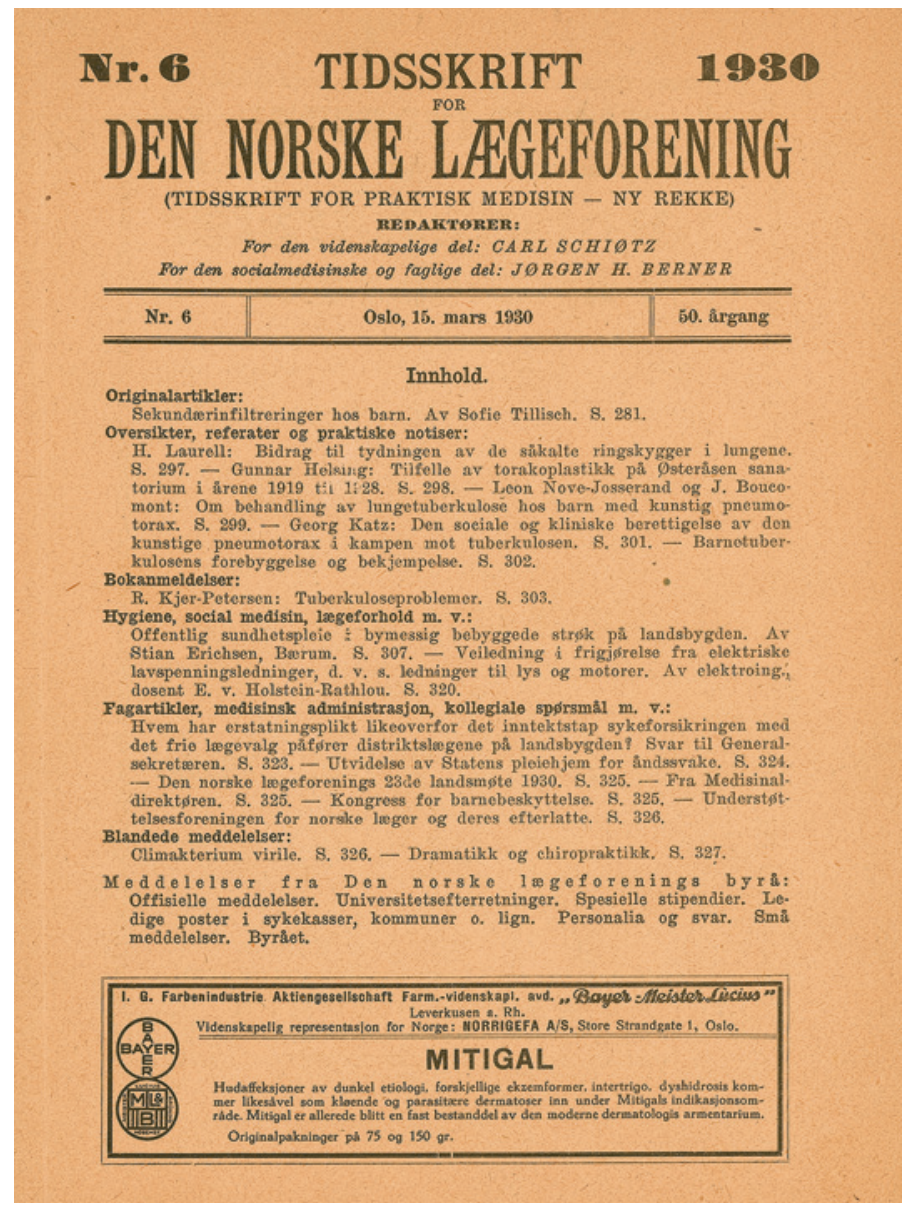

fremdeles gå frem efter den kjente formel: suaviter in modo - fortiter in re, da det annet gamle ordsprog vel også fremdeles gjelder: naturam si furca expellas, tamen usque recurret.

Eivind Krogh.

1) Contribution a l'Etude de l'âge critique - Thèse de Bourdeaux. 1928.

2) I Moll: Die Sexualperioden. 1926

3) Die Wechseljahre des Mannes. Neurolog. Centralblatt 1910 